\title{
Prevalence and pattern of restorations on permanent molar teeth among adult dental patients
}

\author{
Enabulele $\mathrm{JE}^{1}$ and Ehizele $\mathrm{AO}^{2 *}$ \\ ${ }^{1}$ Department of Restorative Dentistry, School of Dentistry, University of Benin, Benin City, Edo State, Nigeria \\ ${ }^{2}$ Department of Periodontics, School of Dentistry, University of Benin, Benin City, Edo State, Nigeria
}

\begin{abstract}
Objective: To assess the prevalence and pattern of restorations on permanent molar teeth among adult dental patients.

Method: This was a cross-sectional descriptive study involving patients who presented to the Restorative clinic of the University of Benin Teaching Hospital. The molars of the participants were examined and classified as restored, unrestored or missing. The restored molars were further examined for type of restoration and status of the restoration whether defective or not. Statistical analysis was done using IBM SPSS version 21.0. Descriptive statistics was carried out on the generated data and chi square statistics was used to determine the statistically significant differences between variables.

Results: A total of 708 molars in 54 participants were examined and classified as restored, unrestored or missing. Prevalence of restored molars was $12.0 \%$ while the prevalence of unrestored and missing molars was $83.8 \%$ and $4.2 \%$ respectively. A higher proportion of restored molars were seen in female participants (67.8\%). There was a statistically significant association between the status of the molar and type of molar teeth ( $\mathrm{p}=0.001$ ), with the first molar being the most frequently restored molar (45.9\%). The lower arch had a higher prevalence (13.6\%) of restored molars. The most prevalent type of material used for restoration was amalgam (83.5\%) while composite and gold crown restorations accounting for $1.2 \%$ each. Majority $(81.1 \%)$ of the restorations were not defective.
\end{abstract}

Conclusion: There was a high prevalence of restored molars with the first molars being the most restored molars and amalgam the most frequent restoration placed.

\section{Introduction}

A review of studies on the morpho-chemistry of the hard tissue of teeth revealed that the different types of the enamel structure is as a result of the different shapes and sizes of the smallest structural units (apatite crystals), the orientation of the enamel prisms as well as the content of the interprismatic enamel spaces and enamel tunnels [1]. This may explain the unequal resistance of the enamel surface to demineralization seen in different individuals $[1,2]$. This suggests that certain tooth types in specific location in the oral cavity may be more prone to demineralization.

Molars may be more prone to the demineralization of hard tissues occasioned by dental caries because of their peculiar anatomical features that enable them to perform the function of chewing and grinding. The dimension of these anatomical pits and features determine the extent of the demineralization process [3]. Deep pits and fissures give room for more food particles to be retained and for more production of acid by bacteria action. It can therefore be suggested that deeper pits and fissures on the molars may increase the severity of demineralization of the hard tissues and make pulpal involvement more likely. This significant contribution of occlusal fissures on molars to their demineralization has been documented [4].

It was also reported that maxillary teeth are more susceptible to demineralization than mandibular teeth [4]. Morphologically, the occlusal surfaces of molars are made up of three to five cusps, divided by fissures, grooves, and pits and linked together by ridges [5]. The maxillary molars may be more susceptible to demineralization because of the oblique ridges found on the occlusal surfaces of maxillary molars [5].
It is widely reported that de-mineralization of teeth due to caries is higher among children $[1,2,6]$, it is necessary to confirm that the caries experience is truly low among adults and that the reduction in prevalence that may have been observed in adults is not as a result of the loss of teeth affected by caries.

The type of restoration on a molar depends on the site of the lesion, the extent of the demineralization and the level of pulpal involvement. Other determinants of the type of restoration to be placed on a molar include operator's level of skill, cost of treatment and mode of payment as well as the patients' preference [7]. Possible dental restorations on a molar range from coronal restorations using amalgam $[8,9]$ or posterior composite [10-13] to acrylic and porcelain crowns [14,15] as well as all metal crowns [15] to onlays and inlays fabricated with gold or other metal alloys [16].

Considering the foregoing coupled with the poor oral health utilisation and limited health resources in developing countries it is pertinent to ascertain the molar teeth that are readily susceptible to caries as well as ascertain the type of restorations mostly sought after for molars in our environment. Furthermore, studies have evaluated the trend of posterior teeth restoration [13] however there is limited

${ }^{\star}$ Correspondence to: Enabulele Joan E, Department of Restorative Dentistry, School of Dentistry, University of Benin, Edo state, Nigeria, Email: emien. enabulele@uniben.edu

Key words: molar teeth, restorations, pattern

Received: February 28, 2019; Accepted: March 14, 2019; Published: March 16, 2019 
knowledge on the prevalence and pattern of restorations on permanent molar teeth hence, this study which was designed with the objective to determine the prevalence and pattern of restorations provided for molar teeth.

\section{Methodology}

Ethical approval for this cross-sectional descriptive study was obtained from the Research and Ethics committee of the University of Benin Teaching Hospital. The study participants were randomly selected from the pool of patients who presented to the Restorative clinic of the University of Benin Teaching Hospital for treatment. Only patients who gave informed consent were included.

Sociodemographic data of the study participants were collected, and all their molars were examined. The molars were classified as restored, unrestored or missing. The type of the restorations on the restored molars were noted and the status of the restorations was classified as defective or not defective.

Statistical analysis was done using IBM SPSS version 21.0. The unit of analysis was the molar teeth. Statistical analysis in the form of descriptive statistics and chi square was carried out with $p$ value set at 0.05 .

\section{Results}

A total of 59 patients were recruited for the study with ages ranging from 20 to 69 years and a mean age of $36.4 \pm 11.1$ years. The age group most represented was the $30-39$ years accounting for $40.6 \%$ of the participants. There was a male preponderance with males accounting for $59.3 \%$ of the study population (Table 1 ).

A total of 708 molars was examined and classified as restored, unrestored or missing. Prevalence of restored molars was $12.0 \%$ while the prevalence of unrestored and missing molars was $83.8 \%$ and $4.2 \%$ respectively.

There was statistically significant association between the status of the molar and type of molar teeth $(\mathrm{p}=0.001)$, with the first molar being the most frequently restored molar (45.9\%) and the third molar being the most frequently missing molar, accounting for $63.3 \%$ of the missing molars (Table 2).

Furthermore, Table 3 shows a statistically significant association between the status of the molar and the molar teeth. The most restored teeth were the mandibular second molars $(25.9 \%)$ followed by the maxillary and mandibular first molars accounting for $24.7 \%$ and $21.2 \%$ respectively. The least restored molar was the maxillary third molar representing $4.7 \%$ of the restored molars.

Table 4 shows that the lower arch had a higher prevalence (13.6\%) of restored molars however, there was no statistically significant association between the status of the molar and the $\operatorname{arch}(\mathrm{p}=0.311)$.

Table 1. Age and gender distribution of the participants

\begin{tabular}{|c|c|c|}
\hline & Frequency & Percent \\
\hline Age group (years) & & \\
\hline $20-29$ & 20 & 33.9 \\
\hline $30-39$ & 24 & 40.6 \\
\hline 40 and above & 15 & 25.5 \\
\hline Gender & & \\
\hline Male & 35 & 59.3 \\
\hline Female & 24 & 40.7 \\
\hline Total & 59 & 100.0 \\
\hline
\end{tabular}

Table 2. Status of molars of the participants

\begin{tabular}{|c|c|c|c|c|c|c|}
\hline & \multicolumn{3}{|c|}{ Status of molar } & & \\
\hline & restored & unrestored & Missing & total & X2 value & P value \\
\hline Molar & $\mathrm{n}(\%)$ & $\mathrm{n}(\%)$ & $\mathrm{n}(\%)$ & $\mathrm{n}(\%)$ & 29.18 & 0.001 \\
\hline $1^{\text {st }}$ molar & $39(45.9)$ & $193(32.5)$ & $4(13.3)$ & $236(33.3)$ & & \\
\hline $2^{\text {nd }}$ molar & $34(40.0)$ & $195(32.9)$ & $7(23.3)$ & $236(33.3)$ & & \\
\hline $3^{\text {rd }}$ molar & $12(14.1)$ & $205(34.6)$ & $19(63.3)$ & $236(33.3)$ & & \\
\hline Total & $85(100.0)$ & $593(100.0)$ & $30(100.0)$ & $708(100.0)$ & & \\
\hline
\end{tabular}

Table 3. Association between status of the molar and the molar teeth

\begin{tabular}{|c|c|c|c|c|}
\hline & restored & unrestored & Missing & \\
\hline & n (\%) & n (\%) & n (\%) & n (\%) \\
\hline Maxillary $1^{\text {st }}$ molar & $21(24.7)$ & $96(16.2)$ & $1(3.3)$ & $118(16.7)$ \\
\hline Maxillary $2^{\text {nd }}$ molar & $12(14.1)$ & $104(17.5)$ & $2(6.7)$ & $118(16.7)$ \\
\hline Maxillary $3^{\text {rd }}$ molar & $4(4.7)$ & $104(17.5)$ & $10(33.3)$ & $118(16.7)$ \\
\hline Mandibular $1^{\text {st }}$ molar & $18(21.2)$ & $97(16.4)$ & $3(10.0)$ & $118(16.7)$ \\
\hline Mandibular $2^{\text {nd }}$ molar & $22(25.9)$ & $91(15.3)$ & $5(16.7)$ & $118(16.7)$ \\
\hline Mandibular $3^{\text {rd }}$ molar & $8(9.4)$ & $101(17.1)$ & $9(30.0)$ & $118(16.7)$ \\
\hline Total & $85(100.0)$ & $593(100.0)$ & $30(100.0)$ & $708(100.0)$ \\
\hline
\end{tabular}

$\mathrm{X}^{2}=34.06, \mathrm{p}$ value 0.001

Table 4. Status of molar by arch

\begin{tabular}{|c|c|c|c|c|c|}
\hline & Upper arch & Lower arch & Total & $\mathbf{X}^{2}$ value & P value \\
\hline Status of molar & $\mathrm{n}(\%)$ & $\mathrm{n}(\%)$ & $\mathrm{n}(\%)$ & 2.236 & 0.311 \\
\hline Restored & $37(10.4)$ & $48(13.6)$ & $85(12.0)$ & & \\
\hline Unrestored & $304(85.9)$ & $289(81.6)$ & $593(83.8)$ & & \\
\hline Missing & $13(2.7)$ & $17(4.8)$ & $30(4.2)$ & & \\
\hline Total & $354(100.0)$ & $354(100.0)$ & $708(100.0)$ & & \\
\hline
\end{tabular}

More than half $(59.3 \%)$ of the participants had at least one restored molar. The number of restored molars per participant ranged from 1 to 7 with a mean of $2.43 \pm 1.79$ restored molars. Figure 1 depicts the distribution of restored molars among the participants. One restored molar was the most frequent finding (37.1\%) followed by 2 restored molars $(34.3 \%)$ and the least frequent finding was 5 restored molars $(2.9 \%)$.

The most prevalent type of material used for restoration was amalgam accounting for $83.5 \%$ while the least restoration was composite and gold crown accounting for $1.2 \%$ each (Figure 2). Majority (81.1\%) of the restorations were not defective while the remaining $18.9 \%$ were defective.

\section{Discussion}

Filled teeth is a component of the DMFT index which is commonly used to determine dental caries prevalence although this index does not state the type of restoration and the condition of the restoration [17]. The molar teeth have been reported as one of the most restored permanent teeth [18]. The prevalence of restored molars in this study was $12.0 \%$ while the prevalence of unrestored and missing molars was $83.8 \%$ and $4.2 \%$ respectively. A pattern different from that reported among dentists (22\% unrestored, $75 \%$ restored and $2 \%$ missing molar teeth) [19].

Multiple restored molars were observed in this study with the first permanent molars being the most frequently restored molars in this study. This could be because the first permanent molars are the teeth most commonly affected by caries and subsequently get restored. While the third molars were the most frequently observed missing molars, a finding different from previous report where it was observed that the first molars were the most frequently missing teeth [20]. 


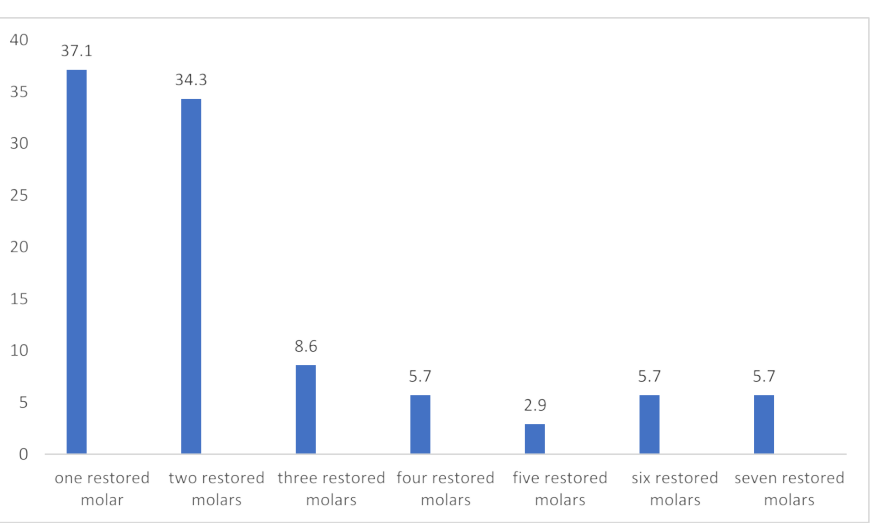

Figure 1. Number of restored molars among the respondents

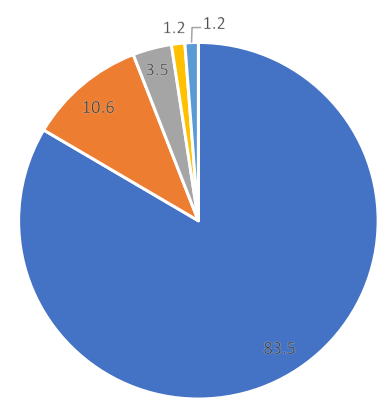

- amalgam " zinc oxide eugenol " porcelain crown " gold crown " composite

Figure 2. Distribution of restorations on the molars

The lower arch had a higher prevalence of restored molars compared to the upper arch. This supports previous observations that the distributions of restorative materials tend to vary by age, arch type, and location in the mouth [21]. In like manner the lower arch had a higher prevalence of missing teeth a finding similar to a previous report [22].

The mean number of restored molars $(2.43 \pm 1.79)$ observed in this study is higher than a previous report of $0.9 \pm 1.6$ [23]. This difference can be attributed to the fact that this present study only included molars while the previous study involved all teeth.

The type of material used for restorations of molar teeth in this study have also been reported as intracoronal restorations in permanent molar teeth in previous studies $[3,24,25]$. The most prevalent type of material used for restoration was amalgam, a finding similar to that of previous reports [21]. However, the prevalence was much higher in this study. This probably may be because aesthetic alternatives to amalgam require more complex procedures, more time and more cost making amalgam still a convenient restorative material for posterior teeth [26], with amalgam rates remaining high in circumstances such as replacement restorations and restorations involving more than one surface [27]. Also, dentists tend to be of the opinion that amalgam has longer longevity [25], hence they may be more inclined to place amalgam restorations. Furthermore, despite the widespread utilisation of alternate dental materials, amalgam restorations are still highly placed [27] especially in posterior load-bearing teeth and in patients with high-caries risk [28].

Defective restorations were observed in this study lending credence to the fact that restorations are known to fail no matter the material used [24].

\section{Conclusion}

There was a high prevalence of restored molars with the first molars being the most restored molars and amalgam the most frequent restoration placed. Furthermore, there were defects in some of the restorations. It is essential therefore that in determining the prevalence of caries, the filled component should also incorporate the type of restorations and the status of the restoration. This will serve as an aid in determining what kind of restoration is readily available to the populace.

\section{References}

1. Kunin AA, Evdokimova AY, Moiseeva NS (2015) Age-related differences of tooth enamel morphochemistry in health and dental caries. The EPMA Journal 6: 3.

2. Neel AAE, Aljabo A, Strange A, Ibrahim S, Coathup M, et al. (2016) Demineralizationremineralization dynamics in teeth and bone. International Journal of Nanomedicine 11: 4743-4763.

3. Avelino de Paiva MA, Leite DFBM, Farias IAP, Costa AC, Sampaio FC (2019) Dental Anatomical Features and Caries: A Relationship to be Investigated. Retrieved from http://dx.doi.org/10.5772/intechopen.71337. (Accessed on 17/01/19)

4. Demirci M, Tuncer S, Yuceokur AA (2010) Prevalence of caries on individual tooth surfaces and its distribution by age and gender in university clinic patients. Eur J Dent 4: 270-279. [Crossref]

5. Marinetti GA (2018) Anatomical and Functional Characteristics of Teeth. Inside Dental Technology. 2018. Retrieved from https://idt.cdeworld.com/courses/5157-Anatomical and_Functional_Characteristics_of_Teeth (Accessed on 10/01/19)

6. Sabel N, Robertson A, Nietzsche S, Norén JG (2012) Demineralization of enamel in primary second molars related to properties of the enamel. ScientificWorldJournal 2012: 587254. [Crossref]

7. Al-Madi EM, Al Saleh SA, Bukhary SM, Al-Ghofaily MM (2018) Endodontic and restorative treatment patterns of pulpally involved immature permanent posterior teeth. International Journal of Dentistry 1-5.

8. Hyson JM Jr (2006) Amalgam: Its history and perils. J Calif Dent Assoc 34: 215-229 [Crossref]

9. Shenoy A (2008) Is it the end of the road for dental amalgam? A critical review. $J$ Conserv Dent 11: 99-107. [Crossref]

10. Parolo CF, Macarevich A, Jardim JJ, Maltz M (2011) Amalgam versus resin composite for restoration of posterior teeth: Disparities between public clinical practice and dental education in Southern Brazil. Rev Fac Odontol Porto Alegre 52: 33-37.

11. Ben-Gal G, Weiss EI (2011) Trends in material choice for posterior restorations in an Israeli dental school: Composite resin versus Amalgam. J Dent Educ 75: 1590-1595.

12. Normann NA, Polan AA, Jan CM, Rashid F, Taleb A (2013) Amalgam and composite restoration for posterior teeth. Bangl J Dent Res Educ 3: 30-35.

13. Gbadebo SO, Anifowose OO, Ogunrinde TJ (2013) Trend of posterior teeth restoration at ibadan, Nigeria. $J$ West Afr Coll Surg 3: 70-83. [Crossref]

14. Tyliszczak B, Drabczyk A, Kudlacik-Kramarczyk S (2017) Acrylates in Denta Applications, Acrylic Polymers in Healthcare, Boreddy S.R. Reddy, IntechOpen. 2017. Available from: https://www.intechopen.com/books/acrylic-polymers-in-healthcare/ acrylates-in-dental-applications

15. Sede MA, Enabulele JE (2016) Types and materials used for fabrication of fixed dental prostheses at a Nigerian tertiary healthcare center. Tanz Dent $J$ 19: 38-42.

16. Sequeira-Byron P, Fedorowicz Z, Carter B, Nasser M, Alrowaili EF (2015) Single crowns versus conventional fillings for the restoration of root-filled teeth. Cochrane Database of Systematic Reviews.

17. Banava S, Fattah M, Kharrazifard MJ, Safaie T, Askerzadeh SH, et al. (2012) Clinical comparison of dental caries by DMFT and ICDA systems. J Islam Dent Assoc Iran 24: $146-151$.

18. Shaffer JR, Poik DE, Feingold E, Wang X, Cuenco KT, Weeks DE, et al. Demographic, socioeconomic and behavioural factors affecting patterns of tooth decay in the permanent dentition: Principal components and factor analyses. Community Dent Oral Epidemiol 41: 364-373.

19. Rosenstiel SF, Land MF, Rashid RG (2004) Dentists' molar restoration choices and longevity: A web-based survey. J Prosthet Dent 91: 363-367. [Crossref] 
20. Baqar A, Mirza D, Ahmed S, Hakeem S (2014) Pattern of missing teeth in Patients seen in prosthodontic department in a teaching hospital of Karachi. Pak Oral Dent J 34: 366-369.

21. Albertini TF, Kingman A, Brown LJ (1997) Prevalence and distribution of dental restorative materials in US Air Force veterans. $J$ Public Health Dent 57: 5-10. [Crossref]

22. Sanya BO, Ng'ang'a PM, Ng'ang'a RN (2004) Causes and pattern of missing permanent teeth among Kenyans. East Afr Med J 81: 322-325. [Crossref]

23. Xu W, Lu H, Li C, Zeng X (2014) Dental caries status and risk indicators of dental caries among middle-aged adults in Shanghai, China. J Dent Sci 9: 151-157.
24. Hickel R, Manhart J (2001) Longevity of restorations in posterior teeth and reasons for failure. J Adhes Dent 3: 45-64. [Crossref]

25. Palotie U, Vehkalahti MM (2009) Finnish dentists' perception of the longevity of direct dental restorations. Acta Odontol Scand 67: 44-49.

26. Roulet JF (1997) Benefits and disadvantages of tooth-coloured alternatives to amalgam J Dent 25: 459-473. [Crossref]

27. Brennan DS, Spencer AJ (2003) Restorative service patterns in Australia: Amalgam, composite resins, and glass ionomer restorations. Int Dent J 53: 455-463.

28. Khalaf ME (2016) Factors relating to contemporary usage pattern of amalgam and resin composite for posterior restorations. Paper presented at the 19th America Dental Congress Phoenix USA.

Copyright: (C2019 Enabulele JE. This is an open-access article distributed under the terms of the Creative Commons Attribution License, which permits unrestricted use, distribution, and reproduction in any medium, provided the original author and source are credited. 